\title{
Localization of ghrelin and its receptor in the reproductive tract of Holstein heifers
}

\author{
S. E. Deaver, ${ }^{* 1}$ P. B. Hoyer, † S. M. Dial, $\ddagger$ M. E. Field, ${ }^{* 2}$ R. J. Collier, ${ }^{*}$ and M. L. Rhoads ${ }^{* 1,3}$ \\ ${ }^{*}$ Department of Animal Sciences, \\ †Department of Physiology, and \\ łDepartment of Veterinary Science and Microbiology, University of Arizona, Tucson 85721
}

\section{ABSTRACT}

The aim of this experiment was to localize the mRNA and protein of ghrelin and its active receptor, growth hormone secretagogue 1A (GHS-R1A), within the reproductive tract of dairy cattle. Ghrelin is an orexigenic hormone that has been identified as a potent regulator of energy homeostasis. Recent evidence suggests that ghrelin may also serve as a metabolic signal to the reproductive tract. Ghrelin and GHS-R1A have been identified in the reproductive tract of several species, including humans, mice, and rats. However, ghrelin and GHS-R1A expression have not been described within bovine reproductive tissues. Therefore, the ampulla, isthmus, uterine body, corpus luteum, and follicles were harvested from 3 Holstein heifers $(15.91 \pm 0.07$ mo of age) immediately following exsanguination. Duodenum and hypothalamus were collected as positive controls for ghrelin and GHS-R1A, respectively. Tissues were fixed in $10 \%$ formalin and embedded in paraffin for microscopy. Additional samples were stored at $-80^{\circ} \mathrm{C}$ for detection of mRNA. Ghrelin and GHS-R1A mRNA and protein were observed in all tissue types within the reproductive tract of dairy heifers; however, expression appeared to be cell specific. Furthermore, ghrelin protein appeared to be localized to the cytoplasm, whereas GHS-R1A protein was found on the plasma membrane. Within the reproductive tissues, ghrelin mRNA and protein were most abundantly expressed in the ampulla of the oviduct. Concentrations of GHS-R1A were lower than those of ghrelin but differed between tissues. This is one of the first studies to provide molecular evidence for the presence of ghrelin and GHS-R1A within the entire reproductive tract. However, implications for fertility remain to be determined.

\footnotetext{
Received March 5, 2012.

Accepted September 25, 2012.

${ }^{1}$ Current address: Department of Animal and Poultry Sciences, Virginia Polytechnic Institute and State University, Blacksburg, 24061

${ }^{2}$ Current address: Department of Animal Sciences, Colorado State University, Fort Collins 80523.

${ }^{3}$ Corresponding author: rhoadsm@vt.edu
}

Key words: ghrelin, ghrelin receptor (GHS-R1A), dairy cattle

\section{INTRODUCTION}

The active form of bovine ghrelin is a 27-AA peptide with a posttranslational n-octanoylation at the serine 3 residue, which is essential for receptor activation (Dickin et al., 2004; van der Lely et al., 2004). Originally discovered as a natural endogenous ligand for the growth hormone secretagogue receptor, ghrelin is a potent regulator of growth hormone secretion (Kojima et al., 1999). Although it is primarily secreted from the X/A-like cells of the oxyntic gland in the stomach, ghrelin expression has also been observed in several peripheral tissues, including the kidneys, pancreas, bowel, hypothalamus, pituitary, and lung (Kojima et al., 1999; Date et al., 2000; Hayashida et al., 2001; van der Lely et al., 2004). The functional ghrelin receptor, growth hormone secretagogue receptor 1A (GHS-R1A), belongs to a large family of rhodopsin-like G-protein coupled, 7-transmembrane domain receptors (Howard et al., 1996; McKee et al., 1997). It is most commonly expressed in the anterior pituitary; however, GHS-R1A mRNA has also been detected in several other tissues (Muccioli et al., 2004). The wide distribution of ghrelin and its functional receptor suggest that it may have a more extensive range of effects than originally believed.

In addition to its ability to stimulate growth hormone secretion, ghrelin promotes appetite and feeding behavior (Kojima and Kangawa, 2005; Wertz-Lutz et al., 2006). Ghrelin is an acute regulator of feed intake; circulating ghrelin concentrations increase during fasting or negative energy balance, and exogenous administration of ghrelin stimulates feed intake in rats and cattle (Wren et al., 2000; Wertz-Lutz et al., 2006; Bradford and Allen, 2008). Ghrelin also influences energy metabolism and increases metabolic efficiency in rodents and cattle (Tschöp et al., 2000; Itoh et al., 2006). Thus, it appears that ghrelin is a key metabolic component involved in the physiological response to energy insufficiency. 
Cattle often experience states of energy insufficiency during normal production cycles, especially during early lactation when the metabolic demand to support milk production is high. In cattle, negative energy balance is associated with decreased fertility, which is most likely an adaptive response to avoid additional metabolic demands associated with pregnancy (Lucy et al., 1992; Beam and Butler, 1997). Evidence from other species indicates that ghrelin may be involved in this process. Analyses in rats, humans, mice, and other species have detected ghrelin and GHS-R1A in several reproductive tissues such as the ovary, uterus, and placenta (Gnanapavan et al., 2002; Caminos et al., 2003; Barreiro and Tena-Sempere, 2004). Moreover, in vitro culture in the presence of ghrelin inhibits the development of preimplantation mouse embryos (Kawamura et al., 2003). Effects on embryonic development are of particular interest because others have shown that cattle experiencing negative energy balance (WertzLutz et al., 2006), as well as cattle with greater genetic merit for milk production (Roche et al., 2006), have higher circulating concentrations of ghrelin . Thus, ghrelin could be contributing to early embryonic loss and decreased fertility in these females.

Although many studies have investigated ghrelin and its receptor in relation to mouse, rat, and human reproduction, none have focused on the role of ghrelin in cattle reproduction. In fact, ghrelin and GHS-R1A have not yet been localized in the reproductive tissues of dairy cattle even though expression has been thoroughly documented in other species. As a first step toward understanding the interactions between ghrelin and fertility in dairy cattle, the current study assessed the expression and cellular location of ghrelin and GHS-R1A in the reproductive tissues of Holstein heifers, with the hypothesis being that both are present throughout the tissues of the bovine reproductive tract.

\section{MATERIALS AND METHODS}

\section{Animals}

Three Holstein heifers $(419.4 \pm 53.0 \mathrm{~kg} ; 15.91 \pm 0.07$ mo of age) were housed in a group pen at the University of Arizona Dairy (Tucson). Animals were fed a TMR composed primarily of alfalfa hay, steam-flaked corn, whole cottonseed, and a commercially available vitamin and mineral mix for ad libitum consumption twice daily at 0700 and $1700 \mathrm{~h}$. The ration was designed to meet or exceed their nutritional demands for growth (NRC, 2001). All animal experiments were reviewed and approved by the University of Arizona Institutional Animal Care and Use Committee.

\section{Tissue Collection}

Estrus cycles of the heifers were synchronized using an Ovsynch protocol in preparation for tissue collection. Briefly, animals received an injection of $\mathrm{GnRH}$ (Cystorelin, Merial, Duluth, GA; $100 \mu \mathrm{g}$ ) followed by an injection of $\mathrm{PGF}_{2 \alpha}$ (Lutalyse, Pfizer, New York, NY; $25 \mathrm{mg}) 7 \mathrm{~d}$ later and a second GnRH injection $(100 \mu \mathrm{g})$ $2 \mathrm{~d}$ after that. Ovarian follicular and luteal structures were measured by transrectal ultrasonography (Aloka SSD-900V ultrasound scanner with a $7.5-\mathrm{MHz}$ probe, Aloka Co. Ltd., Tokyo, Japan) before ovulation and ovulation was subsequently verified. Ovarian structures were again measured at the University of Arizona abattoir just before slaughter, which occurred $7 \mathrm{~d}$ after ovulation. Reproductive tissues [ovarian follicles and corpora lutea (CL), oviductal ampulla and isthmus, and uterine horn and body] were collected immediately following slaughter, fixed for $24 \mathrm{~h}$ in $10 \%$ formalin, and embedded in paraffin for microscopy. Samples from the duodenum were simultaneously collected for comparative purposes. Hypothalamic tissue was collected from another animal to serve as a control tissue for immunohistochemistry. Additional samples from the reproductive tract were immediately snap-frozen in liquid nitrogen and stored at $-80^{\circ} \mathrm{C}$ until RNA extraction.

\section{Blood Samples}

Blood samples were collected at $1000 \mathrm{~h}$ on $\mathrm{d}-2$ (proestrus), 0 (second GnRH injection of Ovsynch protocol), and 7 (diestrus) by coccygeal venipuncture. Blood was collected into evacuated glass tubes containing EDTA (BD Vacutainer, Franklin Lakes, NJ) and immediately placed on ice. Following collection, plasma was harvested by centrifuging the samples for $15 \mathrm{~min}$ at $1,500 \times g$. Plasma samples were treated with $50 \mu \mathrm{L}$ of $1 \mathrm{~N} \mathrm{HCl}$ and $10 \mu \mathrm{L}$ of phenylmethylsulfonyl fluoride $\left(\mathrm{C}_{7} \mathrm{H}_{7} \mathrm{FO}_{2} \mathrm{~S}\right.$; Sigma, St. Louis, MO) per $\mathrm{mL}$ of plasma, according to the kit instructions for analysis of ghrelin by RIA. All samples were frozen and stored at $-20^{\circ} \mathrm{C}$.

\section{Hormone Analysis}

Plasma ghrelin concentrations were measured in a single assay using a commercial RIA kit specific for the biologically active form of ghrelin (kit GHRA-88HK, Linco Research, St. Louis, MO). The intraassay CV was $2.53 \%$. The kit is specific for the human acylated form of ghrelin, so a validation procedure was performed on bovine plasma. Serial dilutions (1:1, 1:2, 1:4, $1: 8$, and 1:16) of 4 bovine plasma samples were made in duplicate, which produced curves that were parallel to the standard curve (slopes of -17.02 and -20.27 for 
Table 1. Sequences of primers and GenBank accession numbers for ghrelin and growth hormone secretagogue 1A (GHS-R1A) whose mRNA abundance was measured using reverse transcription-PCR analysis

\begin{tabular}{llllr}
\hline Gene & Accession no. & Primer & ${\text { Sequence }\left(5^{\prime} \text { to } 3^{\prime}\right)}$ & Nucleotide range $^{1}$ \\
\hline Ghrelin & AY903701 & Forward & CTGAAGAAACCCTGGCTAAC & $329-349$ \\
& & Reverse & CGTGGTCTCGGAAGTGTC & $435-453$ \\
GHS-R1A & XM_592014 & Forward & CCTGGCTCTGTGGAGATC & $917-935$ \\
& & Reverse & CCCGAGAACTTTCATCCTTTAG & $1115-1137$ \\
\hline
\end{tabular}

${ }^{1}$ The nucleotide range refers to GenBank sequence.

the standard curve and serially diluted bovine samples, respectively). Recovery was tested by adding active ghrelin $(450 \mathrm{pg} / \mathrm{mL})$ to bovine plasma with known concentrations of endogenous ghrelin. Recovery of exogenous ghrelin was good, being $106 \%$.

\section{Analysis of Gene Expression}

Total cellular RNA was isolated from each tissue using the TRIzol reagent (Invitrogen, Carlsbad, CA) and Phase Lock Gels (Eppendorf AG, Hamburg, Germany) according to the manufacturers' instructions. The RNA was then cleaned with the RNeasy Mini Kit (Qiagen, Valencia, CA) and DNase-treated with the RNase-Free DNase set (Qiagen). The RNA content of each sample was calculated based on absorbance at $260 \mathrm{~nm}$. The RNA quality was evaluated by calculating the ratio of absorbance at 260 and $280 \mathrm{~nm}$, followed by Bioanalyzer (Agilent Technologies Inc., Santa Clara, CA) analysis; the RNA was stored at $-80^{\circ} \mathrm{C}$. The SuperScript First Strand Synthesis System for reverse transcription-PCR (Invitrogen) was used to reverse transcribe $2.1 \mu \mathrm{g}$ of RNA to first-strand cDNA.

Real-time quantitative reverse transcription-PCR using SYBR Green I dye was used to evaluate ghrelin and GHS-R1A expression in reproductive tract tissues. Primers for each gene of interest were designed using Primer Express Software (Applied Biosystems, Foster City, CA; Table 1). The PCR reactions were performed in triplicate in a $25-\mu \mathrm{L}$ volume using iQ SYBR Green Supermix (Bio-Rad, Hercules, CA). The PCR reactions were performed and fluorescence was quantified by using the ABI Prism 7300 Sequence Detector (Applied Biosystems). For each assay, 40 PCR cycles were run and a dissociation curve was included to verify the amplification of a single PCR product. Analyses of amplification plots were performed with the Sequence Detection Software (Applied Biosystems). Data were analyzed using a 6-point standard curve generated using serial 10-fold dilutions of plasmid DNA $\left(3 \times 10^{6}, 3 \times 10^{5}, 3 \times 10^{4}\right.$, $3 \times 10^{3}, 3 \times 10^{2}$, and $3 \times 10^{1}$ copies of plasmid DNA). Briefly, PCR products were TA (transferase activity) cloned using the pCR 2.1-TOPO kit (Invitrogen) and transformed into Mach1 T1 phage-resistant, chemically competent Escherichia coli (Invitrogen), according to the manufacturer's instructions. Plasmid DNA was extracted using the QiaPrep MiniPrep Kit (Qiagen) per the manufacturer's instructions, and purity and concentration were checked on a nanodrop spectrophotometer (NanoDrop Technologies, Wilmington, DE). Nucleotide sequence and orientation were confirmed by sequencing. Each assay plate contained negative controls and the standard curve to determine amplification efficiency of the respective primer pair.

\section{Immunofluorescent Staining}

Slide Preparation. Five-micrometer sections from CL, follicle, ampulla, isthmus, uterine horn, duodenum, and hypothalamus tissue were mounted on slides treated with poly-L-lysine. Slides were baked at $60^{\circ} \mathrm{C}$ for $30 \mathrm{~min}$, cooled to room temperature $\left(24^{\circ} \mathrm{C}\right)$, deparaffinized, and rehydrated.

Immunofluorescent Staining of Ghrelin and $\boldsymbol{G H S - R 1 A}$. All sections underwent an antigen retrieval process by microwave treatment in $0.01 M$ sodium citrate buffer ( $\mathrm{pH} \mathrm{6.0)}$ for $7 \mathrm{~min}$, and were allowed to cool to room temperature $\left(24^{\circ} \mathrm{C}\right)$ before further analysis. Sections were blocked for $1 \mathrm{~h}$ at room temperature in 10\% fetal bovine serum (Atlanta Biologicals, Lawrenceville, GA), and then incubated with a primary antibody against either ghrelin (rabbit anti-ghrelin; 1:50; Affinity Bioreagents, Golden, CO) or GHS-R1A (rabbit anti-GHS-R1A; 1:50; Millipore, Billerica, MA) overnight at $4^{\circ} \mathrm{C}$. AlexaFluor 488 secondary antibody (donkey anti-rabbit; 1:500; Invitrogen) was applied for $1 \mathrm{~h}$ followed by TOPRO3 (2 nM; Invitrogen) as a nuclear stain, for $10 \mathrm{~min}$, both at room temperature. Slides were rinsed repeatedly with PBS between all incubations. After incubation in TOPRO3, slides were covered with a fluorescent mounting medium (Dako, Carpenteria, CA), coverslipped, and stored in the dark at $4^{\circ} \mathrm{C}$ until visualization. Immunofluorescence was visualized on a Leica confocal microscope with a xenon light source (Leica Microsystems Inc., Bannockburn, IL). Intensity of the immunofluorescence was determined with an argon-krypton laser being projected through the tissue into a photomultiplier tube at $\lambda=488$ and 
$647 \mathrm{~nm}$ for AlexaFluor 488 (green) and TOPRO3 (red) respectively.

\section{Statistical Analyses}

Data were analyzed using the GLM procedure of SAS (SAS Institute Inc., Cary, NC). For analysis of plasma ghrelin concentrations, effects of day and heifer were included in the model. The model for ghrelin and GHS-R1A mRNA data included the effects of tissue and proximity to CL. Heifer was included as a repeated variable. Results are reported as means \pm standard deviations. Correlations between variables were assessed with the CORR procedure of SAS. Statistical significance was declared at $P<0.05$ and tendencies were reported at $P<0.10$.

\section{RESULTS}

\section{Plasma Ghrelin Concentrations, Ghrelin mRNA, and Peptide Expression}

Plasma ghrelin concentrations did not differ throughout the estrous cycle $(P>0.10)$ or between animals $(P$ $>0.10)$.

Amplification of the ghrelin signal was detected in all tissue types within the reproductive tract, with the greatest expression being observed in the ampulla $(P<$ 0.01; Table 2). Ghrelin copy numbers were extremely low in the endometrium, CL, and follicle, actually falling below the lowest point on the standard curve for the assay. Ghrelin expression did not differ based on proximity to the CL $(P>0.10)$.

Ghrelin immunofluorescence was detected in all tissue types within the reproductive tract (Figure 1). Nega-

Table 2. Quantitative real-time reverse transcription-PCR analyses for abundance (copy number means \pm SD per $50 \mathrm{ng}$ of cDNA) of ghrelin and growth hormone secretagogue receptor 1A (GHS-R1A) within the reproductive tissues ${ }^{1}$

\begin{tabular}{lcc}
\hline Tissue & Ghrelin & GHS-R1A \\
\hline Uterine horn & & \\
$\quad$ Ipsilateral & $20.23 \pm 8.36$ & $19.82 \pm 3.82$ \\
$\quad$ Contralateral & $47.88 \pm 67.75$ & $13.52 \pm 6.71$ \\
Endometrium & $19.12 \pm 6.71$ & $32.77 \pm 8.55$ \\
$\quad$ Ipsilateral & $23.26 \pm 7.89$ & $38.37 \pm 17.46$ \\
$\quad$ Contralateral & & \\
Ampulla & $4,484.33 \pm 2,428.67$ & $34.80 \pm 8.61$ \\
$\quad$ Ipsilateral & $4,538.21 \pm 2,370.97$ & $30.42 \pm 11.60$ \\
$\quad$ Contralateral & $109.64 \pm 49.43$ & \\
Isthmus & $399.66 \pm 534.64$ & $39.73 \pm 11.63$ \\
$\quad$ Ipsilateral & $15.73 \pm 8.09$ & $16.94 \pm 8.73$ \\
$\quad$ Contralateral & $9.13 \pm 0.97$ & $15.80 \pm 8.70$ \\
$\quad$ Corpus luteum & & \\
Follicle &
\end{tabular}

${ }^{1}$ For ghrelin, means between tissues differ at $P<0.01$; for GHS-R1A, means between tissues differ at $P<0.05$. tive sections incubated in the absence of the ghrelin antibody exhibited no positive staining, and duodenum was used as a positive control (Figure 1). Positive immunostaining was detected within the cytoplasm of the cell in all tissue types. For the ampulla and isthmus, ghrelin expression was observed in the secretory cells of the columnar epithelium, with the strongest expression being observed on the luminal side. Immunofluorescence in the uterine horn was localized to the endometrial glands. Expression appeared to be cell specific, with individual cells having varying levels of staining. In the follicle, the strongest expression was seen in the granulosa cells lining the antrum, with minimal staining observed in the theca cells. Following suit, positive detection was limited to the large luteal cells in the CL.

\section{GHS-R1A mRNA and Protein Expression}

Amplification of GHS-R1A was present for all tissue types within the reproductive tract (Table 2). However, for several tissues (uterine horn, CL, and follicle), the number of detected copies fell below the lowest point on the standard curve (30 copies). Expression of GHS-R1A differed between tissues $(P<0.05$; Table 2$)$; however, it did not differ based on proximity to the CL $(P>0.10)$. Positive immunofluorescent staining was detected in all tissue types, whereas negative sections incubated in the absence of the GHS-R1A antibody exhibited no positive staining (Figure 2). Hypothalamus was used as the positive control and showed positive staining of the plasma membrane surrounding individual cells (Figure 2). Within the ampulla and isthmus, positive staining was identified in the columnar epithelial cells lining the lumen; however, staining was much more diffuse in the isthmus compared with the ampulla. Protein expression within the uterine horn appeared to be limited to the stroma as opposed to the endometrial glands (where ghrelin immunofluorescence was found). Cells lining the antrum of the follicle, as well as cells within the stroma of the ovary, were positive, suggesting that both theca and granulosa cells express GHS-R1A. This distribution of staining was carried over to the CL, with both the large luteal and small luteal cells expressing the receptor.

\section{DISCUSSION}

Recent research suggests that the orexigenic hormone ghrelin may have numerous effects on female reproduction. Although several studies have demonstrated expression of ghrelin and its functional receptor, GHS$\mathrm{R} 1 \mathrm{~A}$, within the reproductive tract of humans and other species, no published reports describe the distribution of ghrelin in the reproductive tissues of dairy cattle 


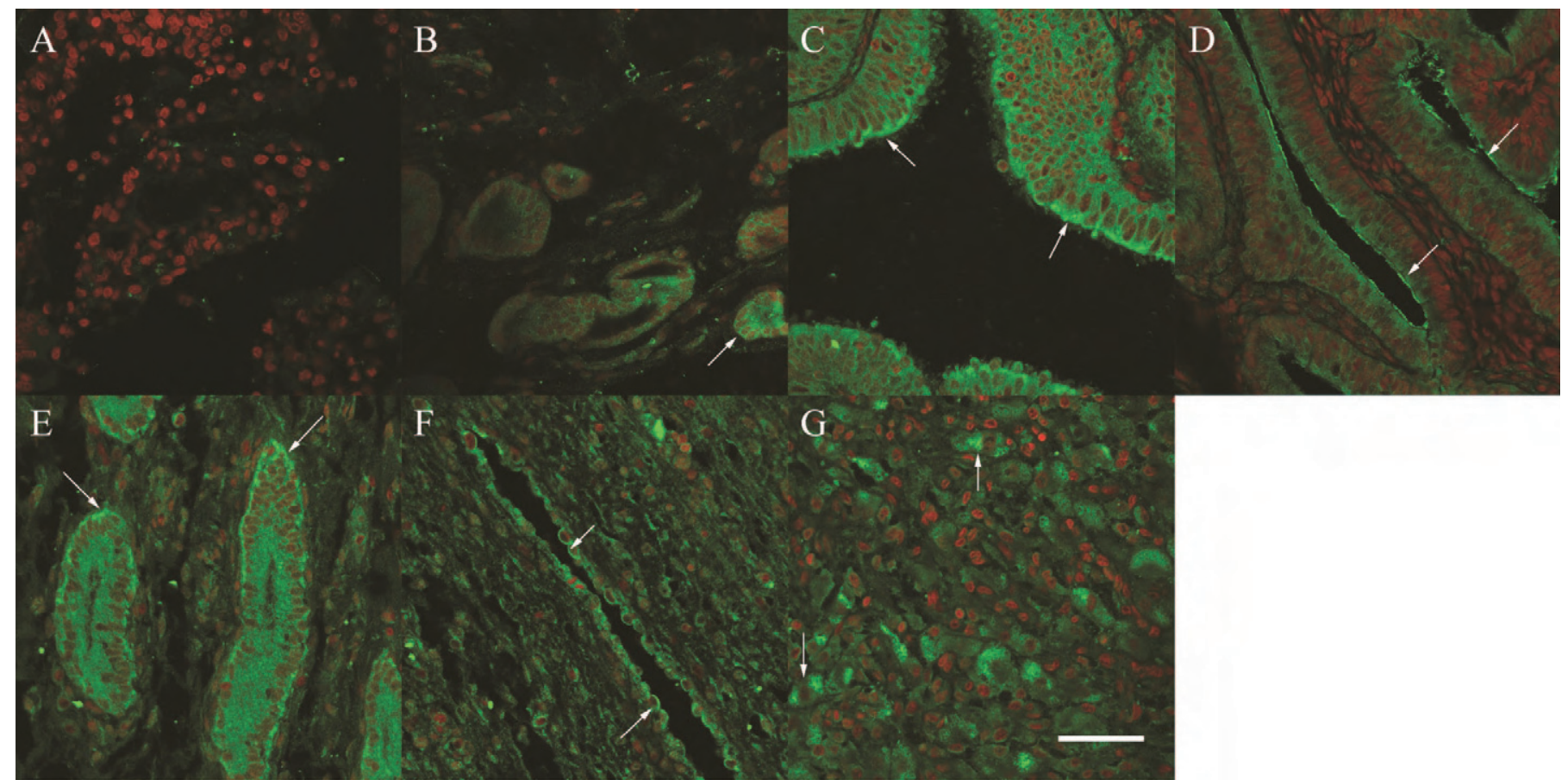

Figure 1. Immunofluorescent detection of ghrelin in the reproductive tissues of dairy cattle. Sections were incubated in rabbit anti-ghrelin primary antibody and TOPRO3 was used to visualize nuclei. Panel A shows staining of duodenum without the primary antibody (negative control); panel B (duodenum) was used as a positive control. Ghrelin expression was detected in ampulla (C), isthmus (D), uterine horn (E), follicle $(\mathrm{F})$, and corpus luteum $(\mathrm{G})$. Green $=$ ghrelin; red $=$ nuclear stain. Arrows indicate positive staining. Scale bar $=50 \mu \mathrm{m}$.

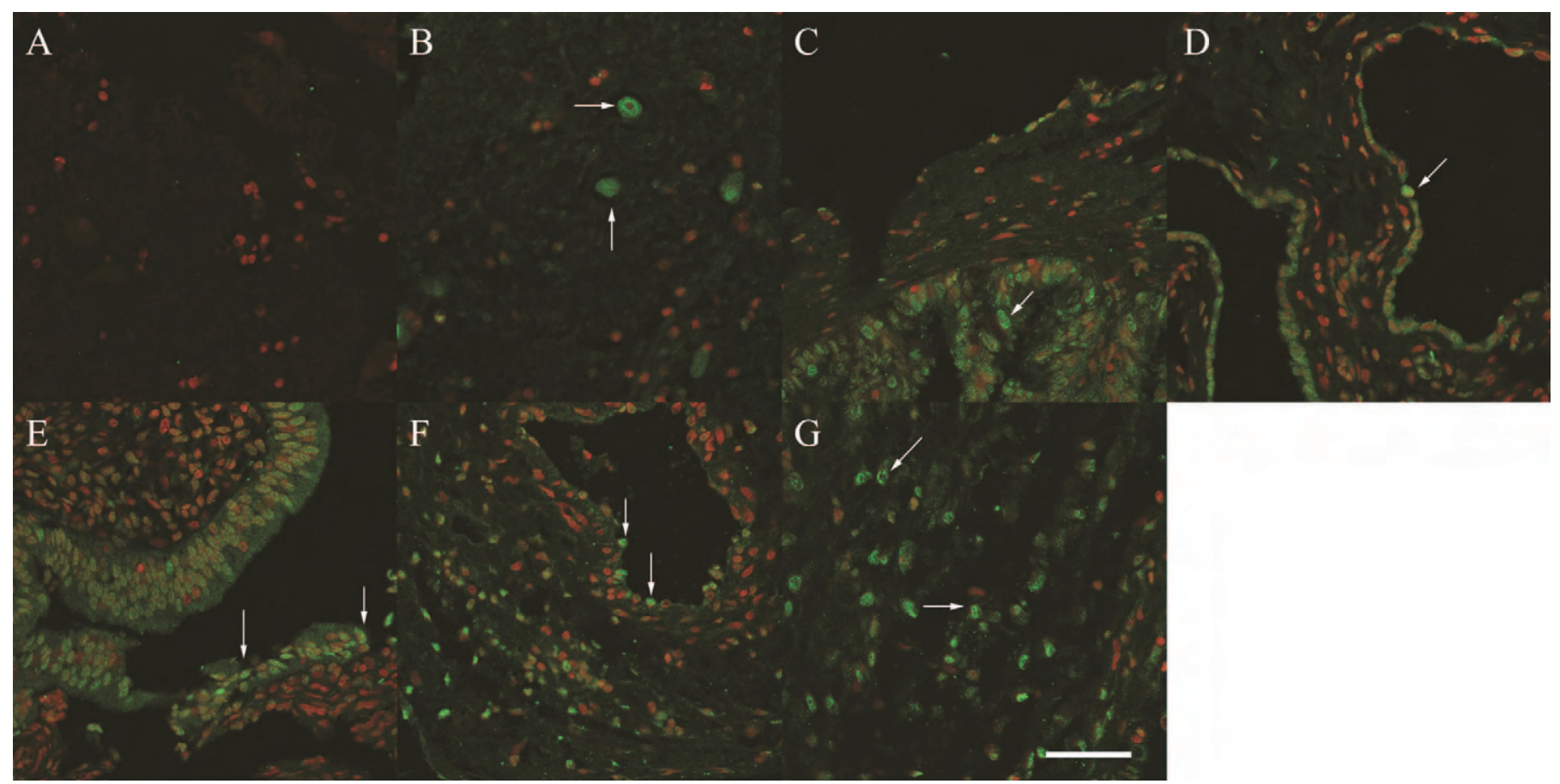

Figure 2. Immunofluorescent detection of growth hormone secretagogue receptor 1A (GHS-R1A) in the reproductive tissues of dairy cattle. Sections were incubated in rabbit anti-GHS-R1A primary antibody and TOPRO3 was used to visualize nuclei. Panel A shows staining of hypothalamus without the primary antibody (negative control); panel B (hypothalamus) was used as a positive control. Expression of GHS-R1A was detected in ampulla $(\mathrm{C})$, isthmus $(\mathrm{D})$, uterine horn $(\mathrm{E})$, follicle $(\mathrm{F})$, and corpus luteum $(\mathrm{G})$. Green = GHS-R1A; red = nuclear stain. Arrows indicate positive staining. Scale bar $=50 \mu \mathrm{m}$. 
(Caminos et al., 2003; Gaytan et al., 2003; Du et al., 2009). Additionally, studies conducted in other species have largely focused on the localization and effects of ghrelin on the ovary, rather than the reproductive tract as a whole (Barreiro and Tena-Sempere, 2004; Garcia et al., 2007). The present study provided detailed molecular evidence for the presence of ghrelin and GHSR1A within the reproductive tract of dairy cattle.

Although we did not detect a significant difference in plasma ghrelin concentrations across time in the current study, we observed a trend for lowest levels at proestrus and highest levels in diestrus (data not shown). This observation is consistent with previous research that has shown that although plasma ghrelin concentrations are low during proestrus and peak during diestrus in rats, concentrations do not differ significantly across the estrous cycle (Caminos et al., 2003).

Although the effects of ghrelin are not completely understood, evidence from several other species demonstrates that ghrelin and its receptor are present in the mammalian ovary. For example, in the sheep ovary, ghrelin protein and mRNA were observed throughout the estrous cycle with the highest levels observed during diestrus. Widespread expression of ghrelin protein was identified throughout the ovary, with detectable levels found in the somatic and thecal cells of follicles (at all stages of development), granulosa cells of antral follicles, and in all developmental stages of the CL (Du et al., 2009). Moreover, immunofluorescence of ghrelin was observed in the cytoplasm of steroidogenic luteal cells in the rat and pig and in granulosa cells of growing follicles in the pig (Caminos et al., 2003; Zhang et al., 2008; Rak-Mardyła et al., 2012). These studies support the current results, although it is important to note that ghrelin mRNA levels were extremely low in the follicle and CL of the bovine ovary. This was likely a consequence of distinct expression patterns. Results from confocal microscopy indicated that ghrelin protein was expressed in distinct cell types within the follicle and CL (not homogeneously throughout). These specific cell types made up only a fraction of the tissue that was homogenized for subsequent mRNA analysis, which resulted in a dilution of the target mRNA. Similarly, immunofluorescent staining for ghrelin localized protein expression within the CL, primarily in the steroidogenic large luteal cells. Interestingly, follicular distribution appears to vary between species. Ghrelin protein expression was observed throughout the sheep follicle (Du et al., 2009), whereas it was primarily limited to the granulosa cells in the current study. The present finding is in agreement with previous work performed by Zhang and colleagues (2008) in pigs.

Expression of GHS-R1A has been detected on the follicular, luteal, and surface epithelia of the ovary in rats (Caminos et al., 2003). Likewise, immunohistochemistry demonstrated strong GHS-R1A protein expression in the granulosa and thecal cells of the antral follicle and throughout all stages of the CL in the cyclic human ovary (Gaytan et al., 2003). Protein and mRNA expression of GHS-R1A in the bovine ovary followed a similar pattern in the current study. Receptor mRNA concentrations were low in all reproductive tissues. Nonetheless, positive fluorescent staining was evident in the theca and granulosa cells of the follicle, as well as small and large luteal cells.

The widespread distribution of ghrelin and GHSR1A in the ovary, coupled with evidence from previous studies, suggests that ghrelin may serve as a regulator of ovarian function. Ghrelin has been shown to exert inhibitory effects on steroidogenesis in humans and rabbits, resulting in decreased progesterone and estradiol$17 \beta$ concentrations (Viani et al., 2008; Sirotkin et al., 2009). Furthermore, recent research has shown that culturing porcine luteal cells in the presence of ghrelin resulted in decreased production of progesterone by

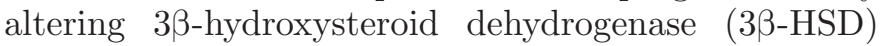
expression and activity in the CL (Rak-Mardyła et al., 2012). However, in other studies, the opposite has been shown, with ghrelin inducing estradiol secretion in granulosa and theca cells by stimulating aromatase activity and increasing progesterone secretion from granulosa cells in pigs (Rak and Gregoraszczuk, 2008; Rak et al., 2009; Sirotkin and Meszarošová, 2010). Additionally, ghrelin induced the expression of proliferative markers and decreased the expression of apoptotic markers in ovarian cells of chickens, pigs, and rabbits (Sirotkin and Grossmann, 2008; Sirotkin et al., 2009; Sirotkin and Meszarošová, 2010). The addition of ghrelin 1-18, a truncated analog of ghrelin, also resulted in an increase in proliferative markers and a decrease in apoptotic markers such as p53 and bax (Sirotkin et al., 2011). Given the expression of both ghrelin and its receptor within the bovine ovary and the effects of ghrelin on steroidogenesis and cell viability in multiple species, the current data suggest that ghrelin may be affecting ovarian cell dynamics in cattle.

Compared with the ovary, little research has been performed to characterize the expression of ghrelin in the uterus. Ghrelin mRNA was expressed in mouse uterine endometrium, and immunohistochemical staining of the protein was observed in the luminal and glandular epithelia of the endometrium. Moreover, ghrelin was detected in uterine fluid, and ghrelin concentrations were significantly higher in both plasma and uterine fluid of mice $48 \mathrm{~h}$ after fasting compared with nonfasted controls (Kawamura et al., 2003). Ghrelin and GHS-R1A mRNA have also been detected in nonpregnant and decidualized human endometrial cells 
(Tanaka et al., 2003). In the current study, both ghrelin and GHS-R1A were expressed within the uterus. However, ghrelin protein was localized to endometrial glands, whereas GHS-R1A protein was limited to the stroma in the bovine uterus.

In terms of ghrelin and GHS-R1A expression in the oviduct, only limited information is available in the literature. Expression has only been described in humans in a single study, in which cellular-specific expression was not determined (Gnanapavan et al., 2002). The current study found that mRNA and protein for both ghrelin and GHS-R1A were present within the ampulla and isthmus. In both tissue types, immunofluorescent staining was localized to the secretory cells of the columnar epithelium, particularly the luminal side. However, staining for GHS-R1A was much more diffuse in the isthmus than in the ampulla. Based on mRNA and immunofluorescence data from the current study, it appears that the ampulla may be an important site of action for ghrelin in the reproductive tract, one that has been mostly overlooked in previous studies.

\section{CONCLUSIONS}

We localized the expression of ghrelin and GHS-R1A mRNA and protein within the major reproductive tissues of dairy cattle. Recent research in several other species indicates that ghrelin is a potential metabolic regulator of reproductive processes. In the current study, ghrelin and its receptor were found throughout the reproductive tract of dairy cattle. Although these findings alone do not prove the existence of a relationship between ghrelin and fertility, they are a mandatory first step toward understanding the role of ghrelin in metabolic regulation of fertility in dairy cattle.

\section{ACKNOWLEDGMENTS}

This research project was supported by National Research Initiative Competitive Grant No. 2005-3520316041 from the USDA Cooperative State Research, Education, and Extension Service.

\section{REFERENCES}

Barreiro, M. L., and M. Tena-Sempere. 2004. Ghrelin and reproduction: A novel signal linking energy status and fertility? Mol. Cell. Endocrinol. 226:1-9.

Beam, S. W., and W. R. Butler. 1997. Energy balance and ovarian follicle development prior to the first ovulation postpartum in dairy cows receiving three levels of dietary fat. Biol. Reprod. $56: 133-142$.

Bradford, B. J., and M. S. Allen. 2008. Negative energy balance increases periprandial ghrelin and growth hormone concentrations in lactating dairy cows. Domest. Anim. Endocrinol. 34:196-203.

Caminos, J. E., M. Tena-Sempere, F. Gaytan, J. E. Sanchez-Criado, M. L. Barreiro, R. Nogueiras, F. F. Casanueva, E. Aguilar, and C.
Dieguez. 2003. Expression of ghrelin in the cyclic and pregnant rat ovary. Endocrinology 144:1594-1602.

Date, Y., M. Kojima, H. Hosoda, A. Sawaguchi, M. S. Mondal, T. Suganuma, S. Matsukura, K. Kangawa, and M. Nakazato. 2000. Ghrelin, a novel growth hormone-releasing acylated peptide, is synthesized in a distinct endocrine cell type in the gastrointestinal tracts of rats and humans. Endocrinology 141:4255-4261.

Dickin, J. C., T. D. Thue, and F. C. Buchanan. 2004. An alternative splice site in ghrelin is missing in ruminants. Anim. Genet. $35: 411-412$

Du, C., Xilingaowa, G. Cao, C. Wang, H. Li, Y. Zhao, Siqingaowa, and J. Cao. 2009. Expression of the orexigenic peptide ghrelin in the sheep ovary. Domest. Anim. Endocrinol. 36:89-98.

Garcia, M. C., M. Lopez, C. V. Alvarez, F. Casanueva, M. TenaSempere, and C. Dieguez. 2007. Role of ghrelin in reproduction. Reproduction 133:531-540.

Gaytan, F., M. L. Barreiro, L. K. Chopin, A. C. Herington, C. Morales, L. Pinilla, F. F. Casanueva, E. Aguilar, C. Dieguez, and M. TenaSempere. 2003. Immunolocalization of ghrelin and its functional receptor, the type $1 \mathrm{~A}$ growth hormone secretagogue receptor, in the cyclic human ovary. J. Clin. Endocrinol. Metab. 88:879-887.

Gnanapavan, S., B. Kola, S. A. Bustin, D. G. Morris, P. McGee, P. Fairclough, S. Bhattacharya, R. Carpenter, A. B. Grossman, and M. Korbonits. 2002. The tissue distribution of the mRNA of ghrelin and subtypes of its receptor, GHS-R, in humans. J. Clin. Endocrinol. Metab. 87:2988-2991.

Hayashida, T. K. Murakami, K. Mogi, M. Nishihara, M. Nakazato, M. S. Mondal, Y. Horii, M. Kojima, K. Kangawa, and N. Murakami. 2001. Ghrelin in domestic animals: Distribution in stomach and its possible role. Domest. Anim. Endocrinol. 21:17-24.

Howard, A. D., S. D. Feighner, D. F. Cully, J. P. Arena, P. A. Liberator, C. I. Rosenblum, M. Hamelin, D. L. Hreniuk, O. C. Palyha, J. Anderson, P. S. Paress, C. Diaz, M. Chou, K. K. Liu, K. K. McKee, S.-S. Pong, L.-Y. Chaung, A. Elbrecht, M. Dashkevicz, R. Heavens, M. Rigby, D. J. S. Sirinathsinghji, D. C. Dean, D. G. Melillo, A. A. Patchett, R. Nargund, P. R. Griffin, J. A. DeMartino, S. K. Gupta, J. M. Schaeffer, R. G. Smith, and L. H. T. d. Ploeg. 1996. A receptor in pituitary and hypothalamus that functions in growth hormone release. Science 273:974-977.

Itoh, F., T. Komatsu, S. Kushibiki, and K. Hodate. 2006. Effects of ghrelin injection on plasma concentrations of glucose, pancreatic hormones and cortisol in Holstein dairy cattle. Comp. Biochem. Physiol. A Physiol. 143:97-102.

Kawamura, K., N. Sato, J. Fukuda, H. Kodama, J. Kumagai, H. Tanikawa, A. Nakamura, Y. Honda, T. Sato, and T. Tanaka. 2003. Ghrelin inhibits the development of mouse preimplantation embryos in vitro. Endocrinology 144:2623-2633.

Kojima, M., H. Hosoda, Y. Date, M. Nakazato, H. Matsuo, and K. Kangawa. 1999. Ghrelin is a growth-hormone-releasing acylated peptide from stomach. Nature 402:656-660.

Kojima, M., and K. Kangawa. 2005. Ghrelin: Structure and function. Physiol. Rev. 85:495-522.

Lucy, M. C., J. D. Savio, L. Badinga, R. L. De La Sota, and W. W. Thatcher. 1992. Factors that affect ovarian follicular dynamics in cattle. J. Anim. Sci. 70:3615-3626.

McKee, K. K., O. C. Palyha, S. D. Feighner, D. L. Hreniuk, C. P Tan, M. S. Phillips, R. G. Smith, L. H. T. Van der Ploeg, and A. D. Howard. 1997. Molecular analysis of rat pituitary and hypothalamic growth hormone secretagogue receptors. Mol. Endocrinol. 11:415-423.

Muccioli, G., F. Broglio, E. Tarabra, and E. Ghigo. 2004. Known and Unknown Growth Hormone Secretagogue Receptors and their Ligands. Pages 27-45 in Ghrelin. Vol. 23. E. Ghigo, A. Benso, and F. Broglio, ed. Springer US.

NRC. 2001. Nutrient Requirements of Dairy Cattle. 7th rev. ed. Natl Acad. Press, Washington, DC.

Rak, A., and E. L. Gregoraszczuk. 2008. Local feedback loop of ghrelin-GH in the pig ovary: Action on estradiol secretion, aromatase activity and cell apoptosis. Growth Horm. IGF Res. 18:221-227. 
Rak, A., D. Szczepankiewicz, and E. L. Gregoraszczuk. 2009. Expression of ghrelin receptor, GHSR-1a, and its functional role in the porcine ovarian follicles. Growth Horm. IGF Res. 19:68-76.

Rak-Mardyła, A., E. L. Gregoraszczuk, A. Karpeta, and M. Duda. 2012. Expression of ghrelin and the ghrelin receptor in different stages of porcine corpus luteum development and the inhibitory effects of ghrelin on progesterone secretion, $3 \beta$-hydroxysteroid dehydrogenase (3 $\beta$-honestly significant difference (HSD)) activity and protein expression. Theriogenology 77:1505-1512. http://dx.doi. org/10.1016/j.theriogenology.2011.11.017.

Roche, J. R., A. J. Sheahan, L. M. Chagas, and D. P. Berry. 2006 Short communication: Genetic selection for milk production increases plasma ghrelin in dairy cows. J. Dairy Sci. 89:3471-3475.

Sirotkin, A. V., and R. Grossmann. 2008. Effects of ghrelin and its analogues on chicken ovarian granulosa cells. Domest. Anim. Endocrinol. 34:125-134.

Sirotkin, A. V., and M. Meszarošová. 2010. Comparison of effects of leptin and ghrelin on porcine ovarian granulosa cells. Domest. Anim. Endocrinol. 39:1-9.

Sirotkin, A. V., M. Meszarošová, R. Grossmann, A. Benčo, and F. Valenzuela. 2011. Effect of inhibitor and activator of ghrelin receptor (GHS-R1a) on porcine ovarian granulosa cell functions. Gen. Comp. Endocrinol. 173:105-110.

Sirotkin, A. V., J. Rafay, J. Kotwica, K. Darlak, and F. Valenzuela. 2009. Role of ghrelin in regulating rabbit ovarian function and the response to LH and IGF-I. Domest. Anim. Endocrinol. $36: 162-172$.
Tanaka, K., H. Minoura, T. Isobe, H. Yonaha, H. Kawato, D. F. Wang, T. Yoshida, M. Kojima, K. Kangawa, and N. Toyoda. 2003. Ghrelin is involved in the decidualization of human endometrial stromal cells. J. Clin. Endocrinol. Metab. 88:2335-2340.

Tschöp, M., D. L. Smiley, and M. L. Heiman. 2000. Ghrelin induces adiposity in rodents. Nature 407:908-913.

van der Lely, A. J., M. Tschop, M. L. Heiman, and E. Ghigo. 2004. Biological, physiological, pathophysiological, and pharmacological aspects of ghrelin. Endocr. Rev. 25:426-457.

Viani, I., A. Vottero, F. Tassi, G. Cremonini, C. Sartori, S. Bernasconi, B. Ferrari, and L. Ghizzoni. 2008. Ghrelin inhibits steroid biosynthesis by cultured granulosa-lutein cells. J. Clin. Endocrinol. Metab. 93:1476-1481.

Wertz-Lutz, A. E., T. J. Knight, R. H. Pritchard, J. A. Daniel, J. A. Clapper, A. J. Smart, A. Trenkle, and D. C. Beitz. 2006. Circulating ghrelin concentrations fluctuate relative to nutritional status and influence feeding behavior in cattle. J. Anim. Sci. 84:32853300 .

Wren, A. M., C. J. Small, H. L. Ward, K. G. Murphy, C. L. Dakin, S. Taheri, A. R. Kennedy, G. H. Roberts, D. G. A. Morgan, M. A Ghatei, and S. R. Bloom. 2000. The novel hypothalamic peptide ghrelin stimulates food intake and growth hormone secretion. Endocrinology 141:4325-4328.

Zhang, W., Z. Lei, J. Su, and S. Chen. 2008. Expression of ghrelin in the porcine hypothalamo-pituitary-ovary axis during the estrous cycle. Anim. Reprod. Sci. 109:356-367. 